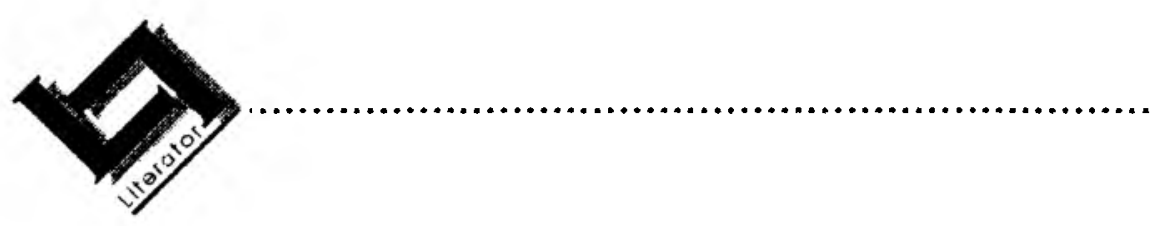

\title{
The real(modern)ist novel
}

Haidar Eid

Department of English

Vista University (Soweto)

BERTSHAM

E-mail: hadar-he@sorex.vista.ac.za

Abstract

The real(modern)ist novel

This article aims to argue that the distinction in both meaning and social function between "realism" and "modernism" lies in their different positions in the economic system of capitalism. The focus point of the article is "modernism" as the cultural logic of monopoly, imperialist capitalism - a logic that never meant a "break oway" from "realism". The article 's dialectical and historical approach to James Joyce's modern text A Portrait of the Artist as a Young Man never accepts the internal modernist logic of the text, i.e. the complete autonomy of a work of art.

Drawing on Fredric Jameson's hermeneutics of ideology and Edward Said's dialectical criticism, the article focuses on the ideological components of $A$ Portrait and will explore its modernity in relation to the political economy of the world that has produced it. Moreover, it will show how A Portrait, as a modernist text, has affiliations with wider fields of power and action.

\section{Introduction}

In this article, I will attempt to illuminate the positive and negative aspetcs of modernism as represented in James Joyce's novel $A$ Portrait of the Artist as a Young Man by arguing against its modernist hero's defense of the the autonomy of art and by suggesting that it is - in our "political unconscious" - related to the monopoly capitalist mode of production. That is to say, my reading of $A$ Portrait is determined by the figuration of the mode of monopoly capitalism. Drawing on Said's notion of "worldliness", I shall suggest that it has strong affiliations with socio-economic "worldly" practices. I will also argue that the modernist "grand 
narrative" concerning the "unworldliness" of the novel is an ideological point that justifies the individual's position in a monopoly capitalist world. However, that is not to say that $A$ Portralt, as a modernist text, is a break from the conventions of the realist novel. Modernism, according to this logic, is a continuity and discontinuity with realism that expresses the battle over social priorities in a rising imperialist capitalism. I will, however, maintain that a dialectical approach to $A$ Portrait cannot but see it as a text with an utopian vision - a vision of an alternative world.

\section{The "new" reality of modernism}

The historical shift from liberal, market capitalism to monopoly imperialist capitalism at the turn of the century was accompanied by radical social changes that - in their turn - contributed to changes in the cultural field. That is to say, the rise of the proletariat as an organized class adopting the "universal" rights that had constituted the basis of the bourgeois public sphere on one hand, and the growth of monopoly capitalism and the rise of imperialism (defined as the most advanced stage of capitalism by Lenin) on the other hand, had brought the old stable universal bourgeois world view to an end. Scott Lash (1990:17-8-9) adds some more factors that accompanied the accumulation of capital and contributed to the transformation of liberal capitalism into an organized capitalism; namely, "forced-paced urbanization", "the growth of transport and communication", "the literacy of the working class", and "the rise of fascism". Hence comes the destabilization of the bourgeois identity, world view, and individualism and, therefore, aesthetic realism. The dialectical relationship between those historical changes - with their socio-economic bases and aesthetic representation culminated in the rise of modernism, an aesthetic movement that, according to Jameson (1991), corresponded in terms of form and content to the organized monopoly capitalism. In this view, modernism was not a rupture or a sharp break away from realism, but rather a new aesthetic form corresponding to a new reality, to a new historical epoch, and thus to a "new" individual/subject.

Taken further, the correlation between the mode of production and literary form, that is monopoly capital and imperialism and modernism, resulted in what seemed to be a move from realism. However, as Jameson (1981:280) argues:

The perfected poetic apparatus of high modemism represses History just as successfully as the perfected narrative apparatus of high realism did the random heterogeneity of the as yet uncentered subject. At this point, however, the political, no longer visible in the modernist texts, and more than in the everyday world of appearance of bourgeois life, and relentlessly driven underground by accumulated reification, has at last become a genuine Unconscious. 
The highly differentiated social structure of modern society - studied by Habermas (1989) - and its atomization of different fields, especially the aesthetic and cultural field, created new modes of representations of the new rising reality, which, consequently, led to the rise of a new cultural reality that is, presumably, distinct from external reality. Moreover, atomization and scepticism led to anti-foundationalism as represented by Nietzsche's sceptical philosophy. With the belief of the disappearance of a foundation, the modern narrative was claimed to have lost its dependence on a foundational external reality. Lash (1990:205), for example, defines modernism as "the absence of externally imposed order on aesthetic practice", which, therefore, develops its own "autonomous ordering". He proceeds to argue that there was a "parallelism" between the emergence of aesthetic modernism and some social factors: the challenge to bourgeois hegemony with the emergence of the working class, urbanization and the "disruption of a stable sense of time and space", the rejection of history, the id and the ego and the discovery of the irrational unconscious (Lash, 1990:206-8). The Dickensian, Tolstoyan, Balzacian treatment of "social totality" and the typology of characters disappeared and were replaced by Joycean epiphanies, streams of consciousness, and what seemed to be the priority of form and style over content. However, this is not to deny the dialectical relationship between the modernist form and its content. The realist narrative as a form corresponded to a specific historical reality that is different from the modernist, and the move was from a realist content to a modernist form within the same socio-economic system which itself had changed its form. That is, realism and early protomodernism are not "diametrically opposed to one another, but [are] ... two sides, form and content, of the same modernizing process in the aesthetic sphere" (Lash, 1990:209).

The distinction in meaning and social function between realism and modernism, then, is related to their different positions in the economic system of capitalism. Modernism, as a new form, was rejected by the philistine Victorian bourgeois who considered it "variously ugly, dissonant, obscure, scandalous, immoral, subversive, and generally 'antisocial'" (Jameson, 1991:4). However, as Jameson argues rightly, modemist works of art are now considered realistic and classical because they represent a different era, and because of the "canonization and academic institutionalization of the modern movement generally" (Jameson, 1991:4). Moreover, the comparison between the two cultural phenomena is - in our political unconscious - related to a deeper comparison between the modes of production of classical market capitalism and imperialist, monopoly capitalism (Jameson, 1981). One can read a modernist work of art from a realist perspective - realisticize it - and a realist work of art from a modernist perspective - modernize it; however, both readings are determined by the figuration of the mode of production, as Jameson would argue.

I will, therefore, briefly analyze a modernist novel against the modernist notion of the complete autonomy of a work of art, and against the Lukacsian views concerning 
modernism, i.e. that objective reality and the 'human condition' are identified with reality itself. Lukacs's distinction between "abstract potentiality" as belonging to the realm of subjectivity, and "concrete potentiality" as concerned with "the dialectic between the individual's subjectivity and objective reality", will be used to approach a classical modernist novel, rather than a realist one. Lukacs (1973:284-5) argues that "[only] in the interaction of character and environment can the concrete potentiality of a particular individual be singled out from the 'bad infinity' of purely abstract potentialities, and emerge as the determining potentiality of just this individual at just this phase of his development". However, he adds that modernist literature invalidates this principle; he even gives Joyce's "stream of consciousness" as an example of "the negation of outward reality", and an example of the presentation of man as "being by nature solitary, asocial, and unable to enter into relationships with other human beings" (Lukacs, 1973:285). Reality in modemist novels, according to Lukacs, is reduced to random impressions of a decadent bourgeoisie consciousness. The modemist novel thus drains reality of its "dialectical content" and transforms it into a nihilistic allegory whose telos is an 'absolute subjectivity'. Nothingness is what modernism contemplates; thus, according to Lukacs, the quest structure which made a socially meaningful narrative possible is undermined in modemism. I will use Lukacs against himself, and against the ideas of Stephen Dedalus, the modernist narrator of James Joyce's novel $A$ Portrait of the Artist as a Young Man. I will, ultimately, argue against the autonomy of art, and defend the idea that literature has affiliations with social practices, i.e. wider fields of power and action. ${ }^{1}$

\section{A Portrait: A realisł reading}

My dialectical approach to James Joyce's "modemist" novel $A$ Portrait is based upon the assumption that there is a dialectical relationship between the inward reality of the narrator and his outward reality. That is, to understand Joyce's novel - as a modernist "master piece" - is to comprehend its relationship to Irish, English, and even continental artistic history and the sociological facts which enter into the novel. Put differently, it is to relate the complex, indirect relations between the novel and the ideological world it inhabits. Indeed, it is the link of tradition between life-world outward reality - and the narrator's world of art that creates the self/other relations that dominate the whole text. In other words, the critical consciousness through which the text is read, reads the political, literary, social, intellectual and economic fields within and without it; it examines, as Said (1975:380) puts it, "the fonnal and psychological questions and interdependence of literary and sociological approaches

1 Pure theoretical consciousness - defended by modemism and deconstructive (post)modernism is, within this context, substituted by "critical consciousness" and "secular criticism", within the realm of the "worldliness" of the novel, as Edward Said does in the The World, The Text, and The Critic (1983) and in Beginnings: Intention and Method (1975) 
... and the questions of liberty, or freedom, or originality as they obtain in complex social and intellectual orders of repetition".

However, Stephen Dedalus, the rising modernist artist, has his own unique modernist aesthetic theory. His clear distinction between the various literary forms is based upon the relation of the artist to his/her material:

The lyrical form is in fact the simplest verbal vesture of an instant of emotion, eurhythmical cry ... The simplest epical form is seen emerging out of lyrical literature when the artist prolongs and broods upon himself ... The narrative is no longer purely personal. The personality of the artist passes into the narration itself, flowing round and round ... The dramatic form is reached when the vitality which has flown and eddied round each person fills every person with such vital force that he or she assumes a proper and intangible esthetic self ... The artist, like the God of the creation, remains within or behind or beyond or above his handiwork, invisible, refined out of existence, indifferent, paring his fingernails (Joyce, 1992:233) 2.

Thus, the novel itself begins with an impersonal opening, but ends with the narrator's notes. The artist has no role, neither social nor political; he is a god paring his fingernails, uninterested in what is going on down on the earth. He is the unified, coherent individual who rejects his worldly home, fatherland, and church. He, therefore, expresses himself "in some mode of life or art as freely as [he] can and as wholly as [he] can..." (268-269). A Portrait - as a modernist work of art written at the turn of the century, the beginning of the age of monopoly capitalism and rising collective working class - glorifies older forms of individual production which are threatened by the new mode production. ${ }^{3} \mathrm{~A}$ transcendental human production makes the artist a god, or a son of God - like Dedalus - and the work of art enables him to transcend family, religion and nationality. This is, of course, a utopian vision of an individualistic human production. Hence Dedalus asks us to read $A$ Portrait as an autonomous work of art produced by an artist/god, a god who can create a world on his own, an artist who has the power and knowledge to hold on to his own individualistic productivity and freedom in an age of collectivity and mass production, a god/centre who/which escapes structurality and interpretation; a "master narrative" which escapes interpretation.

The question of the relationship between the artist and her/his work is, then, one of the fundamental formal motifs of the novel. What Dedalus believes in, in terms of the

2 All quotations from $A$ Portrait will henceforth be followed by page number

3 This is also Jameson's theorization of "protomodernism" which started at the end of the nineteenth century, and with the end of the age of classical market capitalism (Jameson, 1991:307). 
isolation of the artist from the world and from her/his work, is, however, contested paradoxically - by the novel itself. The notion of - to borrow Said's term "worldliness" (1983) within and without the novel, the relations between knowledge, class and power play an extremely important role in the formation of $A$ Portrait. Said (1983:35) writes in The World, The Text, and The Critic that literary works "have ways of existing that even in their most rarefied form are always enmeshed in circumstance, time, place, and society - in short, they are in the world, and hence worldly".

In terms of Said's notion of "worldliness", $A$ Portrait is not, then, a completely isolated self-centred literary work, as one is asked to understand; rather, it is full of different external historical and autobiographical elements that contribute to the creation of the inward reality of the narrator. Rejection of a higher authority, selfjustification and defence, sex, humiliation, love, nationalism - to mention but a few examples - are all elements that underline Dedalus's attitude towards society, and therefore, towards himself as a boy, a man, and as an artist. But $A$ Portrait is also the story of the growth of an artistic "human soul" and mind from early childhood to young manhood, a story of the individual artist's revolt against his father and mother church; a story of his love and sex; a story of his immersion in sin, his treatment of hypocrisy, and his revolt against ideological authoritarian injustice. In other words, even though Dedalus denies the importance of worldly experiences, the novel is the story of the attempts of the individual artist to use all these outward experiences, and relate them to his inward reality in order to formulate and discover a "critical consciousness" and critical art that opens up new possibilities in the nature of the relationships between the artist and his world/environment.

From the very beginning, one is exposed to a primary form of art associated with Dedalus's childhood:

Once upon a time and a very good time it was there was a moocow coming down along the road and this moocow that was coming along the road met a nice little boy named baby tuckoo ... (3).

The primary world is made of art, of story-telling, and of singing. Moreover, this world is the mother who "[has] a nicer smell than [the] father"; the world, in other words, starts with art and the modern patriarchal nuclear family. Family, art, and then politics in the divided opinions between friends of the family, are all motifs which compose - not to say control - the whole text. The father's telling of stories, the mother's dancing and singing, are images of the "very good time" which acquire contextual meaning in the course of the narration of the rest of Dedalus's autobiography. 
This is the beginning of the road through which the boy progresses at school - the second authoritarian institution - where he struggles to comprehend the universe and its impact on him, in particular, and on art in general:

Stephen Dedalus is my name,

Ireland is my nation.

Clongowes is my dwelling place

And heaven my expectation

... what was after the universe? Nothing ... It was very big to think about everything and everywhere (13).

The road is full of obstacles and he has to overcome them. He breaks his glasses and is almost blinded; and he is persecuted at school. But he is insistent on rebelling against persecution and traditions in order to reach a "unique individuality":

He passed along the narrow dark corridor, passing little doors that were the doors of the rooms of the community. He peered in front of him and right and left through the gloom and thought that those must be portraits. It was dark and silent and his eyes were weak and tired with tears so that he could not see (57).

This is the initial step on the road towards his career and literary talent, a road in which religion and pohtics are among the most important intimations of his early childhood.

All of this should come as no surprise since Ireland at the turn of the century is the context. Religious and political arguments conceming the Catholic Church, anticlerical factionalism, and nationalism are what Dedalus is asked to remember when he grows up (33). The politics of rejection and resistance to dogmatic religious and political ideas, resistance to authority, injustice and humiliation--whether political or ideological - become components of his personality. Hence the significance of the Clongowes Wood episode. He has been unable to attend his lectures for a legitimate reason, that is, his glasses have been broken. However, the prefect of studies disciplines him together with other guilty boys. Dedalus's sense of injustice and humiliation motivates him to complain to the rector. Of course, this formulation of authority and resistance leads to self-satisfaction - an important station in the progress of the artist from childhood to adolescence.

Adolescence and aesthetic appreciation begin together and go hand in hand in the novel. Literature starts to be a part of Dedalus's experience, but not as an isolated entity; that is, what it does is a stimulation to his mind and senses. His defence and enthusiasm for Lord Byron provokes a beating at the hands of his friends (6), which proves that a commitment to an artistic position draws social consequences. Moreover, one of his essays is accused of heresy (83). The implication, here, is that writing has ideological dimensions even if it is not conscious of them. Writing, in 
other words, is entangled in an ideological context that imposes an hegemony on it which it resists. The process through which Dedalus becomes conscious of the hegemony of an authoritarian ideology coincides with his sexual initiation as an adult: "nothing stirred within his soul but a cold and cruel and loveless lust ... [and] he was drifting amid life the barren shell of moon" (102). And thus he moves into a new heresy, i.e. sex as a sin. This happens in an experience with a prostitute with whom he gains a new kind of self-confidence: "In her arms he felt that he had suddenly become a string a fearless and sure of humself" (107). This passage equates sex and art on the ground that it leads to moments of freedom and creativity in which "verse passed from his lips and the inarticulate cries and the unspoken brutal words rushed forth from his brain to force a passage" (106).

\section{Intellectual growth}

Fear of authority and its hegemonous ideology stop "the self" from emerging. The intellectual, according to this authoritarian ideology, is not supposed to think of resistance. If $\mathrm{s} / \mathrm{he}$ does, $\mathrm{s} / \mathrm{he}$ is supposed to repent and show remorse. A long terrifying sermon on Hell and the sin of Lucifer is given by the rector. The pride of the intellectual is used as an example for intellectuals among whom is Dedalus, the intellectual sinner. His imagination and consciousness are filled with the torments of the damned intellectual, the intellectual sinner who is supposed to be punished for he has not only slept with a whore, but also has pride. To $\sin$ and to have pride is to rebel against the church and, therefore, become like Lucifer who rebelled against the authority of God. Dedalus, the adolescent, is now a sinner and "[his] sin ... had led him to the refuge of sinners" (112). The price he has to pay is confession, repentance, and complete obedience - not to say subordination. Hence his temporary decision to become the Virgin's knight, and his contemplation of the possibility of the Jesuit order in order to become the reverend Stephen Dedalus, S.J.

However, to become a reverend means complete obedience, a total submission and subjugation to a higher authority: it is not to be one's self, especially if one is an intellectual artist. That is why Dedalus asks himself many theological questions, questions that do not only weaken the ideological rhetoric of the Church, but which also resonate with a radical social critique:

If man had stolen a pound in his youth and had used that pound to amass a huge fortune how much was he obliged to give back, the pound he had stolen only or the pound together with the compound interest accruing upon it or all his huge fortune? If a layman in giving baptism pour the water before saying the words is the child baptised? Is baptism with a mineral water valid? How comes it that while the first beatitude promises the kingdom of heaven to the poor of heart the second beatitude promises also the meek that they shall possess the land? (114) 
And then comes the most important theological question, i.e. whether or not Jesus Christ is God or man. The consciousness evinced here is the kind of critical secular consciousness that aims to arrive at a sense of political, social, ideological and human values, a consciousness that deals with, as Said (1983:26) writes, "local and worldly situations, and [that is] constitutively opposed to the production of massive, hermetic systems". These are the questions that provide resistance to theological hegemony, that open up new horizons in the intellectual's consciousness toward "historical reality, toward society, toward human needs and interests ..." (Said, 1983:242). Such elements draw concrete instances from reality, which, ultimately, contradict Dedalus's views concerning the isolation of the artist. If he questions whether Jesus Christ is a God or man, it follows, then, that the artist is also a man.

However, the presence of fear, which is the antithesis of courage and freedom, makes Dedalus commit himself, temporarily, to the Church and what it offers, i.e. immaterial reality. Complete subordination is what he is supposed to show in order to regain his sinful soul. The free, autonomous individual - as a project - is, then, postponed, not to say ignored in the presence of a clear-cut theological ideology which wins temporarily in its war against bourgeois secularity represented in Dedalus's previous sceptical and critical questions. In this "religio-metaphysical" phase of his life there is a differentiation between the social, worldly and the sacred and spiritual. He is either the sinful intellectual who has pride and who follows the need of his body, or the priest who "would hold up his tongue" in order to allow God to enter his "purified body" (158). Put differently, this phase is characterized by an irreconcilable binary opposition between cultural, social, economic, profane worldly reality, and sacred, priestly, religious, purified "reality" with its subjugation of the individual/subject. This conflict within Dedalus parallels the historical development of the human society from a "primitive" stage to a "religio-metaphysical" phase. Whereas in the "primitive stage" "culture and the social are undifferentiated" (Lash, 1990:6), in the "religiometaphysical' phase there is a dichotomy and schism between worldly culture and the sacred. In Dedalus's childhood, his parents are the source of art, and in his adolescence he is forced to adopt a sharp schism between the social profane and the sacred.

Significantly, the climax of the novel is Dedalus's youth phase in which he discovers, or rather explores the world of aestheticism. The previous interest in priesthood moves to another kind of worship; the appeal to metaphysical religious powers transforms into an appeal to art. Thus the question becomes: why should he deny the life of senses? His reflections now are on how "[he] would create proudly out of the freedom and power of his soul, as the great artificer whose name he bore, a living, new and soaring and beautiful, impalpable, imperishable" (184). Moreover, the centre of his interest is not Christ or the Virgin any more, but rather a girl whose face is like a bird's face; an ordinary girl whose beauty inspires him and fills him with "ecstasy" and a desire for artistic creation, a desire "to live, to err, to fall, to triumph, 
recreate life out of life" (186). And the angel who appears now is not Seraphim or Lucifer, but rather "a wild angel ... the angel of mortal youth and beauty, and envoy from the fair courts of life, to throw open before him in an instant of ecstasy the gates of all the ways of error and glory" (186). This is the phase in which he adopts and defends the idea of the isolation of the artist.

This phase of his life that corresponds to the "modern" phase in humanity in which it is claimed that "each of the cultural spheres attains the fullest possible autonomy" (Lash, 1990:8) is accompanied by a rebellion against his bourgeois nuclear family, Ireland, and Catholicism. That is, it is a rebellion against all symbols of authority that limit his freedom, freedom that is associated with art: "I will try to express myself in some mode of life or art as freely as I can and as wholly as I can" (269). His refusal to submit to a higher authority - family, Church, nationalism - is, in other words, a resistance to what Louis Althusser calls the "State Ideological Apparatus"; a resistance that should lead him to an autonomous individuality. And what he is after now is a confrontation with life and experience: "welcome, $\mathrm{O}$ life! I go to encounter for the millionth time the reality of experience ..." (276).

\section{The "worldliness" of A Portrait}

And yet the question of the "worldliness" of $A$ Portrait as a modern narrative becomes increasingly related to the relationship between Stephen Dedalus and James Joyce himself, between the narrator within the text and the author outside the text. As Malcolm Bradbury and James McFarlane (1991:405) argue rightly, A Portrait is a "Bildungsroman of the symbolist-Modernist artist, Stephen Dedalus, which describes the pursuit of an artistic metamorphosis both as a sympathetic autobiography and as a formally-contained object set in several framing modes". But whose autobiography is it? Dedalus's or Joyce's? Does Dedalus, and thus Joyce, disappear in the impersonal, distanced world of $A$ Portrait? Dedalus's hierarchical classification of different forms of art - lyric, narrative, and dramatic--and his defence of the "unworldliness" of the narrative are ideological points that reflect the position of the subject/individual at the tum of the century. To seek a form, regardless of the content, and to play with this form in order to create a content that reflects (on) itself, i.e. an artistic form that precedes content in which art is practised for art's sake is, undoubtedly, an ideological dilemma. Fredric Jameson (1988:349) in "Cognitive Mapping" describes the inability of modernist writers, at the turn of the century, to write "totality" because the raw materials for such a depiction disappeared. The move from market to monopoly capital witnessed

... a growing contradiction between 'lived experience' and structure, or between a phenomenological description of the life of an individual and a more properly structural model of the conditions of existence of that experience ... The truth of that limited daily experience ... is bound up with the whole colonial system of the British Empire that determines the very 
quality of the individual's subjective life. Yet those structural coordinates are no longer accessible to immediate lived experience and are often not even conceptualizable for most people (Jameson, 1988:349).

Through epiphanies, streams of consciousness, allusions to mythology, and usage of realistic style, Joyce tries to reach a transcendental point through art, transcendence that reflects his "silence, exile, and cunning" by writing the "unpresentable" (Lyotard, 1984). Since the world outside the text is incoherent - from a bourgeois point of view - as a result of the destabilisation of the bourgeois itself, why not escape this world to a new world created and controlled by "me", a world that represents "my" inner self and its disintegration, a world where I can find myself in different forms represented in various artistic forms?

It now becomes clear why all the actions take place in Dedalus's consciousness (and unconsciousness). As Walter Allen (1986:4) writes, "[Dedalus's] consciousness is the novel ...". Reality outside his consciousness is reality outside the novel. Since the patriarchal family, the prostitute, the Church, the school, Dublin, Ireland, i.e. the world, impinge on his consciousness, or rather form and re-form it, it follows, then, that there is a dialectical relationship between his inward and outward realities. However, Dedalus consciously rejects the idea that he is a presupposed self whose content comes from without. His new self-image is, then, claimed to be outside collective consciousness, outside the social self that is recognized by the "Others", and thus is beyond the dialectic of the self/other. This seems to be the influence of Romantic rhetoric conceming the artist's creativity, individuality, isolation, Godhood, and the idea that the artist's ideas, life and art are original notions which spring from her/himself.

A Portrait is a world in itself; and since Dedalus's consciousness is A Portrait, it follows then that his consciousness is a world. His immaturity is reflected in the world he creates as a child, the world of his adolescence, and the world of his youth. His "arrogance" (Allen, 1986) and immaturity are meant to be there in order to create a distance between himself and his creator, i.e. James Joyce. Although the novel is written by Joyce, he - like "the God of creation" - is meant to be beyond it "paring his finger-nails". This is, of course, supposed to defy all exhausted mimetic and realistic forms of literature. Hence Joyce creates and deconstructs Dedalus spontaneously in order to prove that he is an asocial and ahistorical creature who wants to live in "silence [and] exile", and in order to prove that his inner self defines him as forever alienated from external reality. $\mathrm{He}$, in other words, denies the dialectical relationship between his "abstract potentiality" and the dynamic contribution of society and history, as Lukacs would put it (Lukacs, 1973).

And yet, the question of Dedalus's relationship to his world leaves its mark not only on his consciousness, but also on his choice of art and creativity. By choosing art, he chooses himself and relates to the world at the same time; that is to say, by 
developing his aesthetic theory, as a part of himself and of the world, he weaves his literature into the relational whole, i.e. the grand narrative, a choice which family and religion cannot offer to him. In other words, he attains his state, i.e the artist, only after rejecting all the domestic, social and religious demands and restraints imposed upon him. However, their influence on him, despite his resistance, leaves its mark on his psychological growth; he, in other words, cannot reject them without testing and tasting them. What he thinks he reaches is a "true self", a pure autonomous subjectivity as "artist"; or rather a new kind of individuality with a new entity related to further relationships, a "relational holism". Contrary to his concept of individuality, though, he is not Stephen Dedalus, the autonomous individual and the hero of an autonomous novel, but rather the sum of all other sub-individuals with whom he has a direct and indirect relationship. His "newly" discovered identity is the sum of the identities of Byron, Lynch, the mother, the father - Simon Dedalus - and all other Irish national figures. Significantly, the novel starts by using the third person pronoun, and ends by using the first person pronoun. That is, Dedalus starts as an objective witness of the conversation and interaction between his sub-selves, which ultimately leads to unification of all these sub-selves into one unified self, i.e. "I", as a product of all other social relations. Stephen Dedalus is, then, a young writer, living in a bourgeois society, rebelling against the destabilization of his identity, rejecting his environment by denying its existence, and resisting the movement of history by trying to transcend it.

Moreover, moving from one level of consciousness to another is marked with the literary forms and images Dedalus is aware of, and with cries that differentiate each level till he reaches the supposed "autonomous subjectivity". The most remarkable cry is the last one in the scene in which he contemplates the bird-girl, for that is the cry of artistic discovery and self-consciousness. Indeed, his past accumulates in order to form his present: Stephen Dedalus, the artist who signs the novel in Trieste in 1914. According to Dedalus, the self, then, is not found and discovered easily and effortlessly. In order to get to one's true, "original" self, one dismantles the superficial, social self. As Zavarzadeh and Morton (1994:93) argue, this process "has a long tradition in Western mysticism. One dismantles one's ephemeral self on the level of the mundane and voluntary only to find it on a higher plane of reality - and permanently". An easy work is not, then, accepted in the bourgeois ethics which offers a privileged status for those individuals who "work hard" to discover their "genuine selves" through "creativity". Significantly, this concept is defined by Zavarzadeh and Morton (1994:93) as "the quality that is the basis of entrepreneurship in capitalism". According to Dedalus's understanding of art and creativity, the creative artist transcends the material world in order to penetrate the opacities of culture and experience reality in its absolute plenitude - as Zavarzadeh and Morton would put it. The artist thus becomes the maker of his own laws. Within this context, Pierre Machery argues that "the proposition that the writer or artist is a creator belongs to a humanist ideology" (as quoted in Zavarzadeh \& Morton, 
1994:94). By convincing individuals to perceive themselves as "autonomous", "free", and "transcendental entities" beyond material reality, the humanist hegemonous ideology continues its hegemony and domination.

And yet, the materiality of Dedalus's language provides evidence that he cannot free himself from it and from its social background, from what Machery (as quoted in Zavarzadeh \& Morton, 1994:93) calls "the order external to himself", an order and language which are indications of class struggle, ideology, and history. As Althusser (1992:54) argues in another context, he is an individual who thinks that he is "free", but becomes a subject of interpellation in capitalism. The battle over social priorities, at the turn of the century when monopoly capitalism was being formed, between the rising working class - as a force of production and property, had led to the formation of new forms of knowledge among which is modernism. The discourse of modernism, used by Joyce, is undoubtedly a part of the contestation concerning the hegemony of either capitalist or socialist relations of production. Thus, this form is not basically "new", but rather a renewed form of an already existing content. The forms of knowledge available to Dedalus are, then, a part of broader material, social, and historical frames that he has no control over. Why not, then, disassociate oneself from such frames and claim autonomy? If one cannot change collectively, since the forms of knowledge available at that specific moment offer either/or binaries, one is advised to be "one's self". That is, the fiction of a completely free, autonomous individual is the product of an ideology that aims at creating a world of separate entities that do not have a common goal, because, as Zavarzadeh and Morton (1994:135) write, "social change does not come about by voluntaristic undertakings by 'free' individuals". However, the existence of different constraints never means the absence of choice; a fact that is understood by Dedalus who wants to make his own history but never under circumstances of his own making. Hence the idea of the artist's godhood.

The complicated mix between the private and the public worlds in $A$ Portrait consists of Dedalus's personal history, growth, values and positions derived from his own experience on the one hand, and on the other hand, how these enter into the social world where people debate and make decisions (Said, 1994:9). Dedalus is not a private intellectual, but rather an "organic intellectual" - as Gramsci (1986) would call him - who emerges in a monopoly capitalist society, and who develops "a resistant intellectual consciousness before he can become an artist" (Said, 1994:13). However, his solution is an individualistic one that defends withdrawal from one's environment in order to avoid the hegemonous ideological environment, an environment that does not allow one's individuality to emerge in its search for knowledge and freedom beyond patriarchal hierarchy, beyond "distorted communication", beyond national and religious prejudices, beyond the available forms of knowledge, and beyond the exploitation of (wo)man by man. However, no 
one can escape politics even if one tries to escape to a pure, disinterested, transcendental art, because, ironically, this in itself is a political position.

\section{Conclusion}

In this article I have attempted to contextualize the modernist "master narrative" concerning the autonomy of art by historicizing it and by relating it to the monopoly capitalist mode of production. I have maintained that elements of modernity as represented in Joyce's $A$ Portrait, can never be understood if not theorized in relation to the socio-economic sphere and to the elements of power and resistance at the turn of the century. I have also contended that it is only through a dialectical and historical materialist approach that we can see modernism as both "progress" and "catastrophe" at the same time. Hence my conclusion that the dilemma of the modern hero Stephen Dedalus lies in the kind of consciousness the outside objective world tries to create in its attempt to justify the exploitation of (wo)man by man, and his attempts to resist it.

\section{Works cited}

Allen, Walter. 1986 (1964) Tradition and Dream: The English and American Novel from the Twenties to Our Time London: The Hogarth Press

Althusser, Louis. 1992. Ideology and the State. In: Modern Literary Theory: Reader. Philip

Rice and Patricia Waugh. (eds.) London : Edward Amold. p. 54-62.

Bradbury, Malcolm \& McFalane, James 1991 (1976). Modernism: A Guide to European Literature 1890-1930. London Penguin Books.

Gramsci, Antonio. 1986 (1971). Selections from Prison Notebook. Ouintin Hoare and Geofry Nowell Smith. (trans. and eds.) London : Lawrence and Wishart

Habermas, Jurgen. 1989. The Structural Transformation of the Public Sphere: An Inquiry into Category of Bourgeois Society. (Trans. Thomas Burger). Cambridge : the MIT Press

Jameson, Fredric. 1981. The Political Unconscious. London : Methuen.

Jameson, Fredric. 1988. Cognitive Mapping In: Nelson, Cary \& Grossberg, Lawrence. (eds.) Marxism and Interpretation of Culture. London : Macmillan Education p. 347-60.

Jameson, Fredric. 1991. Postmodernism, Or the Cultural Logic of Late Capitalism London Verso

Joyce, James. 1992. A Portrait of the Artist as a Young Man. London : Penguin Books

Lash, Scott. 1990. Sociology of Postmodernism. London : Penguin Books.

Lukacs, George. 1973 (1961). Marxism and Human Liberation. (Ed.) E. San Juan. New York : Delta Book

Lyotard, Jean Francois. 1984. The Postmodern Condition: A Report on Knowledge. (Trans.) Geoff Bennington \& Brian Massumi. Minneapolis : University of Minnesota.

Said, Edward 1983. The World, the Text, and the Critic. London : Faber and Faber

Said, Edward. 1975. Beginnings: Intention and Method. New York : Basic Books.

Said, Edward. 1994. Representations of the Intellectual. London : Vintage.

Zavarzadeh, Mesud \& Morton, Donald. 1994. Theory as Resistance: Politics and Culture after (Post)structuralism New York : The Guilford Press. 